\title{
Editorial
}

\section{Urban Trends in the Iberian Peninsula}

This volume is a result of an effort of members of the IGU commission on "Monitoring Cities of Tomorrow" to explore urban dynamics in different areas of the world and in cities of different cultures, size and functions. This volume is devoted to urban dynamics in the Iberian Peninsula. The articles in the volume deal with three main issues. The first group of articles discusses metropolization processes and some managerial and developmental consequences of this process. The second group of articles deals with managing and planning middle-size cities in the light of Agenda 21 and European polycentric policies. The last group of articles focuses on the inner city, its reconstruction and the development of tourism.

\section{David Herbert, María José Piñeira Mantiñán and Izhak Schnell}

(Guest Editors)

The Geography and Human Environment Department

Tel Aviv University

Israel

E-mail: Schnell@post.tau.ac.il

(C) Izhak Schnell; Licensee Bentham Open.

This is an open access article licensed under the terms of the Creative Commons Attribution Non-Commercial License (http://creativecommons.org/licenses/ by-nc/3.0/) which permits unrestricted, non-commercial use, distribution and reproduction in any medium, provided the work is properly cited. 